\title{
Community Colleges Online
}

Corinne Crawford, Borough of Manhattan Community College, USA

Colin Persaud, Borough of Manhattan Community College, USA

\begin{abstract}
Presently, community colleges are bursting at the seams. In 2011, community colleges turned away more than 400,000 prospective students. In the next six years, 63 percent of all U. S. jobs will require postsecondary education. Twenty two million new workers with postsecondary degrees will be needed by 2018. Community colleges are turning increasingly to online technology to increase capacity in order to meet the surging demand for higher education attainment. In this article we will look at the role of online education in the community college setting.
\end{abstract}

Keywords: Community Colleges; Online Education; Completion Rates

\section{THE ECONOMIC IMPERATIVE OF INCREASING HIGHER EDUCATION ATTAINMENT}

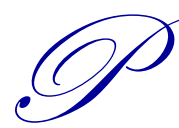

resident Obama has called the need to increase higher education attainment, "an economic imperative". In the next six years, 63 percent of all U.S. jobs will require postsecondary education. Twenty two million new workers with postsecondary degrees will be needed by 2018. In contrast, in 2010, 38.3\% of working age adults held a two- or four year college degree. At the present rate of degree attainment less than $47 \%$ of working age Americans will have at least an associate degree by 2025 . This will leave the United States labor market 23 million degree holders short of the number needed to satisfy workforce demand.

These statistics leave no doubt about the urgent need to increase the pace of higher education attainment. However, education funding is currently being slashed due to the economic downturn and huge budget deficits. For this reason higher education has to become more productive and cost effective in order to have any chance of meeting the post secondary educational needs over the next decade. To this end educational and governmental leaders have been looking to community colleges to fulfill the demand for expanded higher postsecondary education attainment in a cost effective manner.

Unfortunately, community colleges are severely overcrowded. In 2011 community colleges had to turn away 400,000 prospective students. In an attempt to meet this extraordinary demand, community colleges are relying increasingly on online education to serve their ever expanding student body. The following is a discussion of the state of online education in community colleges today and suggestions on how to move forward to attain this important educational goal.

\section{ONLINE EDUCATION MAY IMPEDE THE SUCCESS OF COMMUNITY COLLEGE STUDENTS}

The Community College Research Center studied online learning in the Virginia and Washington State Community College systems between 2004 and 2008. These studies are the largest and most comprehensive conducted to date of online learning in community colleges. The following is a synopsis of the studies' findings.

Students who enrolled in online classes tended to be female, white, fluent in English, age 25 years or older, from higher than average socio-economic groups, academically prepared upon admittance and the care giver of a dependent child.

Students' enrolled in online courses were significantly less likely to complete courses than students enrolled in face-to-face courses. The completion rate for online courses was $11 \%$ to $15 \%$ lower than the completion 
rate for face-to- face courses. The completion rate for online remedial courses was even lower. The completion rate for online remedial math and English courses was $19 \%$ and $24 \%$ lower respectively than completion rate for face-to -face math and English remedial courses. Moreover, students who took online remedial English courses were $30 \%$ less likely to move onto college level English courses than students who took face-to-face remedial English courses. Students who took online remedial math courses were $24 \%$ less likely to move on to college level math courses than students who took face-to-face remedial math courses. Students who enrolled in online courses in early semesters were slightly but statistically significantly less likely to return to school in subsequent semesters.

These research findings suggest that online courses are not as effective as face-to- face courses in educating community college students. The next section will address possible reasons for this discrepancy.

\section{BARRIERS TO SUCCESS FOR ONLINE COMMUNITY COLLEGE STUDENTS}

Barriers to success for online community college students include lack of student engagement, technical difficulties, lack of structure and lack of support services.

Community college student satisfaction surveys for online courses consistently express dissatisfaction with the lack of instructor/student and student/student interaction. Numerous research studies have found that online community college students feel isolated and disconnected due to the impersonal nature of this teaching modality. In a 2011 study, Glazer and Wainstreet found that $40 \%$ of online learners felt no connection with their college. Student disconnection and lack of immediacy are consistently reported as major causes of student withdrawal from online courses.

Multiple research studies have found that engagement is a fundamental basis of student retention. The research suggests engaged students are much more likely to complete course requirements. The lack of engagement of community college online students appears to be a major factor in the higher attrition rate of online courses at community colleges.

Technical difficulties with online courses are another cause of stress that can affect student retention. Online community college students frequently expressed frustration with system failures and their own lack of computer skills. In addition, online community college students reported difficulty with navigating course management systems and following the material on the screen.

Community college students may not have access to high speed internet service at home. In 2007, less than $50 \%$ of all homes with income under $\$ 40,000$ had high speed internet access. In a small study of online remedial math students in a Florida community college the researchers found the $70 \%$ of the students who withdrew from online courses cited computer based technology issues.

The lack of structure in online courses is especially vexing for community college students. Over $90 \%$ of online courses are asynchronous which allows students to access course materials at times which are convenient to them. This creates a low structure course format. Research has shown that community college students in these low structure online environments are less likely to hand in assignments, less likely to participate in class activities and more likely to hand in assignments late. Additionally, community college students have expressed dissatisfaction with low structure environments frequently commenting that they felt as if they had to teach the material to themselves.

To compound the problems online students frequently do not have the same access to support services as on campus students do. Research studies have found that online students have difficulty accessing library support, financial aid services, technical help, advising and tutoring. Numerous research studies have also shown that the inability of community college students to access these vital support services is a major factor in the high attrition rate of online community college classes.

Given the logistical difficulties inherent in this teaching platform and the challenges faced by students with diverse educational backgrounds, online course offerings must be structured to address the educational needs of 
community college students in a way that complements and serves as a comparable alternative to face-to face classes. The next section will address the components of successful online community college programs.

\section{COMPONENTS OF SUCCESSFUL ONLINE COMMUNITY COLLEGE COURSES}

Research has shown that successful community college online programs have the following characteristics:

- Incorporate assessment readiness for online work.

- $\quad$ Provide strong student orientation programs.

- $\quad$ Offer substantial online student support services.

- Include high levels of teaching presence.

These studies have shown that each of these educational components is essential to effective teaching in the online setting and high level student retention in these programs.

\section{Assessing Student's Readiness}

Research has shown that assessing student readiness for online work is a key element in improving student retention. Many community colleges have instituted online readiness instruments that determine whether a student's learning characteristics are compatible with online instruction. These instruments evaluate learning style, computer skills and motivation. These tools have proven successful in increasing student retention and student and faculty satisfaction.

The University of Georgia has developed a model online assessment program, Student Online Readiness Tool, SORT, to help students assess their readiness for online learning. The interactive tool contains modules that identify students', learning styles, technology experience, access to computer tools, study habits, lifestyle and goals and purposes. Students who complete the assessment are given immediate feedback so that they can make an informed decision on the suitability of online learning to meet their educational needs.

In addition to providing a mechanism for student self- assessment the readiness assessment tools have proven successful in other areas. The tools have been used effectively to identify students who may require additional support services to increase the likelihood of a successful outcome. The tools have also been used to limit enrollment in online classes to include only students who are most likely to succeed in the online environment.

\section{Student Orientation}

Student orientation is a valuable tool in increasing student success in online courses. The Community College Research Center at Columbia University suggests that all community colleges require online students to complete a course management tutorial within the first few days of taking their first online course or be deregistered.

The content of the orientation package is crucial. Effective orientation programs provide students with realistic expectations of the online environment. These programs are interactive and introduce students to the types of assignments they will be expected to complete. An important goal of the orientation program is to develop the basic technical and computer skills that will be needed in the course. In addition, this orientation introduces students to institutional policies, procedures and support services.

Both online and face-to-face orientation programs have been shown to be effective in increasing student retention rates. However, only face- to- face orientations have been found to increase the spirit of community among participants. This is an important goal for orientation programs offered to online students as online community college students often cite the absence of community as a reason for dropping online courses.

Consumnes River Community College has an interesting orientation program that has proven effective in increasing online success rates. The "Online Student Success" (OSS) program is offered during the middle of the 
semester to incoming online students and current online students who are experiencing difficulty. The program teaches the students how to navigate the course management system. It also exposes them to the unique challenges of online learning. The students who have completed the program state that it successfully prepared them for online learning and increased their comfort with the online landscape. Like Consumnes Community College, when a mandatory online orientation program was introduced at Richmond Community College, the online student retention rate increased by $8 \%$. Additionally, the computer help desk estimated a $50 \%$ decrease in "trouble tickets".

\section{Sufficient Support Services}

It is important to ensure that online students receive the same support services as face-to-face students. The Community College Research Center of Columbia University recommends that online community college students be provided with 24/7 online support services, including tutoring, technical services and librarian assistance. Lack of proper support for online students is correlated with decreased student success and increased withdrawals.

Regardless of the delivery format, online students should be instructed on how to access support services upon enrolling in online courses. Research studies have shown that online support services are most effective when they are seamlessly integrated into online programs and are easy to navigate. Support services should be displayed prominently in the course material to be even more helpful.

The most effective support system for online learners is a 24 hour technical service desk that provides live assistance. Additionally, online mentors and CD instruction packets have been effectively used to support the online student. Online students at Leslie University are assigned a mentor to guide them through all phases of their online education. Among their many roles, mentors can serve as technical advisors to online students. Leslie University views their mentoring service a key aspect of their successful online program. Many institutions provide students with CD packages that include all needed software applications with detailed instructions upon enrolment in online classes. These CD' packages have proven to be effective support vehicles.

\section{High Level of Teaching Presence}

Teaching presence is defined as "the design, facilitation, and direction of cognitive and social processes for the realization of personally meaningful and educationally worthwhile learning outcomes" (Anderson, Rourke, Garrison and Archer 2001). Considerable amount of research has shown that instructor presence positively impact student's affective learning, cognition and motivation. Additionally, instructor presence has been correlated with fostering a sense of community. A lack of community has been identified as an important factor in the high attrition rate in online community college courses. The following is a discussion of the three dimensions of teaching presence.

Professor presence begins with the design of the class. An online class should be designed just like a faceto-face class. The professor should establish clear learning goals, learning assessments and learning activities. By establishing defined goals, assessments and activities the teacher establishes their initial presence.

Throughout the class the professor should facilitate online discourse. Skillful facilitation will increase students' interaction with each other and with the professor. The professor should model appropriate behavior. The

professor should also encourage, acknowledge and reinforce student contributions. Anderson a pioneer in the field of teaching presence, believes, "facilitating discourse during the course is critical to maintaining interest, motivation and engagement of students in active learning".

Direct Instruction is the third crucial element of online teaching presence. During direct instruction professors disseminate their disciplinary expertise. Direct instruction includes presenting content and questions, focusing the discussion on specific issues, summarizing the discussion, confirming understanding and dispelling misconceptions. 


\section{CONCLUSION}

Community colleges are on the forefront of online education as the largest share of online education enrollment is at the community college level. Presently, online enrollment at community colleges is growing at a substantially faster pace than overall enrollment. In 2011 online enrollment grew by $8.2 \%$ whereas overall enrollment remained flat.

Online education affords flexibility to both students and community colleges. Students are freed from geographic and time constraints. Additionally, community colleges are able to increase course offerings with a minimum investment in technology. Online education holds out the promise of substantially increasing access to postsecondary education at the community college level. If online programs are effectively implemented, community colleges may continue to fulfill their mission of opening the door to the American dream.

\section{AUTHOR INFORMATION}

Corinne Crawford, MBA, CPA is an Assistant Accounting Professor at Borough of Manhattan Community College, CUNY, New York, New York, USA. She spent 15 years in public accounting, Pricewaterhousecoopers and KPMG, before switching careers to teach full-time. Professor Crawford has been teaching at Borough of Manhattan Community College since 2009. Prior to teaching at BMCC, she was an accounting professor and coordinator of the Accounting Department at Marymount Manhattan College. Professor Crawford has published several articles in the CPA Journal. E-mail: CCrawford@bmcc.cuny.edu (Corresponding author)

Colin Persaud, is an Assistant Computer Science Professor at Borough of Manhattan Community College, CUNY New York, New York, USA. He spent 10 years in information technology at Chemical Bank and Citi Bank before switching careers to teach full-time. Professor Persaud has been teaching at Borough of Manhattan Community College since 2004. E-mail: cpersaud@bmcc.cuny.edu

\section{REFERENCES}

1. Alavi, M.; Leidner, D. E. (2001), Research Commentary: Technology-Mediated Learning - A Call for Greater Depth and Breadth of Research. Information Systems Research. Vol. 12(1).

2. Allen, I., Seaman, J., 2011. Going the Distance: Online Education in the United States, 2011. Babson Survey Research Group.

3. Allen, J., Seeman, J. 2006. Making the Grade: Online Education in the United States. Needam, MA: Sloan Consortium.

4. Bates, A.; Poole, G. 2003.Effective Teaching with Technology in Higher Education, San Francisco. JosseyBras/John Wiley.

5. Campbell, H. 2006.Cheating, Public Administration Education, and Online Courses: An Essay and Call to Arms, Journal of Public Affairs Education, Vol. 12(1).

6. Cox, B., Cox, B. 2011.Developing Interpersonal and Group Dynamics through Asynchronous Threaded Discussions: The use of Discussion Board in Collaborative Learning, Education, Vol. 128(4).

7. Crawford, C., Jervis, A., 2011. Community Colleges Today. Contemporary Issues in Education Research, Vol. 4(8).

8. Dykman, C.; Davis, C. 2008.Online Education Forum: Part Two - Teaching Online Versus Teaching Conventionally. Journal of Information Systems Education, Vol. 19(2).

9. $\quad$ Edwards, M., Perry, B., Janzen, K. 2011.The Making of an Exemplary Online Educator. Distance Education, Vol. 32(1).

10. El-Sheikh, E. 2009.Techniques for Engaging Students in an Online Computer Programming Course. Systemics, Cybernetics and Informatics, Vol. 7(1).

11. Fish, W., Wickersham, L. 2009.Best Practices for Online Education, The Quarterly Review of Distance Education, Vol. 10(3).

12. Githens, R., Crawford, F., Sauer, T., 2010. Online Occupational Education in Community Colleges: Prevalence and Contextual Factors. National Research Center for Career and Technical Education. 
13. Glazer, H., Wanstreet, C. 2011. Connection to the Academic Community Perceptions of Students in Online Education. The Quarterly Review of Distance Education, Vol. 12(1).

14. Habib, L., Sonneland, A., 2010.From Alien to Domestic? Virtual Learning Environment Use from a Domestication Perspective. Merlot Journal of Online Learning and Teaching, Vol. 6(4).

15. Hill, C., 2010. Ten Factors that Determine Online Student Success at Community Colleges. Faculty Focus.

16. Hill, J., Reven, A. Online Learning Communities: If You Build Them, Will They Stay? http://it.coe.uga.edu/itforum/paper46/paper46.htm

17. Ibanez, M., Scott L. 2008. Learning to Teach Online Teaching Sociology, Vol. 36(2008).

18. Jaggars, S., 2011. Online Learning: Does It Help Low-Income and Underprepared Students? Community College Research Center, CCRC Working Paper. No. 26.

19. Jaggars, S., Bailey, T., 2010. Effectiveness of Fully Online Courses for College Students: Response to a Department of Education Meta-Analysis. Community College Research Center.

20. Jaggars, S., Xu, D., 2011. Online and Hybrid Course Enrollment and Performance in Washington State Community and Technical Colleges. Community College Research Center, CCRC Working Paper. No. 31.

21. Jaggars, S., Xu, D., 2011. Online Learning in the Virginia Community College System. Community College Research Center.

22. Kim, H. 2011. LMS for the NetGeneration: Students' Perception and Use on Canvas. Annual Sloan-C International Conference on Online Learning 2011.

23. Kim, Y. 2004.Online Education Tools, Public Performance \& Management Review, Vol. 28(2).

24. Lane Community College 2010. Success and Retention in Online and Hybrid Courses Lane Community College Online Teaching and Learning Project Phase 1.

25. Liu, S., Gomez, J., Yen, C., 2009. Community College Online Course Retention and Final Predictability of Social Presence. Journal of Interactive Online Learning, Vol. 8(2).

26. Lokken, F. 2008 Distance Education Survey Results: Tracking the Impact of eLearning at Community Colleges. Washington, D.C.: Instructional Technology Council, 2009.

27. Lorenzo, G., 2011. Online Education Learner Engagement \& Academic Success Strategies at Community Colleges. The Source on Community College Issues, Trends \& Strategies.

28. Mandernach, B., Gonzales, R., Garrett, A., 2008. An Examination of Online Instructor Presence via Threaded Discussion Participation. Merlot Journal of Online Learning and Teaching, Vol. 2(4).

29. Martinez, S., Torres, H., Giesel, V. Determining Student Readiness for Online Instruction. http://www.onlinestuentsupport.org/Monograph/readiness.php

30. Mayes, R., Ku, H., Akarasriworn, C., Leubeck, J., Korkmaz, O. 2011.Themes and Strategies for Transformative Online Instruction, A Review of Literature and Practice, The Quarterly Review of Distance Education, Vol. 12(3).

31. Nagarajan, P., Jiji, G. 2010. Online Educational System (e-learning), International Journal of $u$ and eService, Science and Technology, Vol. 3(4).

32. New Directions for Community College, no 150.Summer 2010. Wiley Periodicals, Inc.

33. Office of Institutional Research and Planning 2011. City College Online Course Satisfaction Survey Report.

34. Perez, E., 2011. Online Community Colleges Students More Likely to Fail, Withdraw. California Watch.

35. Pew Research Center 2011. The Digital Revolution and Higher Education College Presidents, Public Differ on Value of Online Learning.

36. Pontes, M., Hasit, C., Pontes, N., Lewis, P., Siefring, K. Variables Related to Undergraduate Students Preference for Distance Education Classes. http://www.westga.edu/ distance/ojdla/summer132/pontes_pontes132.html

37. Rhoades, G., 2012. Closing the Door, Increasing the Gap: Who's not going to (community) college? Center for the Future of Higher Education Policy Report \#1.

38. Schaeffer, C., Konetes, G., 2010. Impact of Learner Engagement on Attrition Rates and Student Success in Online Learning. http://www.itdl.org/Journal/May 10/article01.htm

39. Selingo, J., 2009. Use of Online Courses at Community Colleges Continues to Grow. http://chronicle.com/article/Use-of-Online-Courses-at/47159

40. The Gates Foundation http://www.gatesfoundation.com

41. The Sloan Consortium http://sloanconsortium.org/ 
42. Vanhorn, S., Pearson, J., Child, J. 2008.The Online Communication Course: The Challenges. Qualitative Research Reports in Communication, Vol. 9(1).

43. Virtual College Leadership Team, 2011. Blueprint for a Virtual College. Shoreline Community College. 
NOTES 